\title{
Biomarkers responses of the earthworm Eisenia fetida to acetochlor exposure in OECD soil
}

\author{
Neng-Wen Xiao ${ }^{\text {a,b }}$, Yan Song ${ }^{b}$, Feng Ge ${ }^{\text {b,* }}$, Xiang-Hui Liu ${ }^{b}$, Zhi-Yun Ou-Yang a \\ ${ }^{a}$ Key Lab of Systems Ecology, Research Center for Eco-Environmental Sciences, Chinese Academy of Science, Beijing 100085, PR China \\ ${ }^{\mathrm{b}}$ State Key Laboratory of Integrated Management of Pest Insects and Rodents, Institute of Zoology, \\ Chinese Academy of Sciences, Beijing 100080, PR China
}

Received 25 October 2005; received in revised form 27 March 2006; accepted 27 March 2006

Available online 8 May 2006

\begin{abstract}
To examine the potential of a suite of biomarkers as early warning indicators of environmental pollution, sperm count, neutral red retention time (NRRT) and DNA damage were measured in earthworm Eisenia fetida exposed to increasing concentrations of acetochlor in OECD soil. The neutral red retention time of earthworms coelomocytes was sensitive to acetochlor pollution, and decreased significantly when the concentration was more than $10 \mathrm{mg} \mathrm{kg}^{-1}$ after 30 and 60 days of exposure $(P<0.05)$. The reduced neutral red retention time correlated with the soil acetochlor residual. Sperm count decreased significantly at the concentrations of 40 and $80 \mathrm{mg} \mathrm{kg} \mathrm{after}^{-1}$ days of exposure $(P<0.05)$. The DNA damage of earthworms coelomocytes increased significantly after 30 days of exposure at the highest concentration $\left(80 \mathrm{mg} \mathrm{kg}^{-1} ; P<0.05\right)$. Earthworms were under physiological stress at field dose of acetochlor $\left(10 \mathrm{mg} \mathrm{kg}{ }^{-1}\right)$. Higher concentrations of acetochlor caused sperm count decrease and DNA damage of earthworms. Such a suite of biomarkers could serve as indicators of the health of the soil environment and to evaluate the toxicity of acetochlor on earthworms or as a means of monitoring soil acetochlor pollution.
\end{abstract}

(C) 2006 Elsevier Ltd. All rights reserved.

Keywords: Acetochlor; Eisenia fetida; Biomarker; Sperm count; Neutral red retention time (NRRT); DNA damage

\section{Introduction}

In the agricultural areas worldwide there is an increasing concern about soil contamination due to the widespread use of pesticides. Acetochlor, as a member of the chloroacetanilide class of broad leaf herbicides, is one of the most widely used herbicide all over the world with a consumption of more than $10^{4} \mathrm{t}$ every year in China (Ye, 2003). It shows significant carcinogenicity to the rat nasal epithelium (Green et al., 2000). Metabolites of herbicides acetochlor induce sister chromatid exchanges in human lymphocytes (Hill et al., 1997). Acetochlor also induce

\footnotetext{
${ }^{*}$ Corresponding author. Tel.: +8610 62948093; fax: +86 1062565689 . E-mail address: Gef@ioz.ac.cn (F. Ge).
}

the reduction of microbial community diversity in soil (Luo et al., 2004). It has been classified as a B-2 carcinogen by the USEPA (1994).

In many ecosystems, earthworms are key species in decomposer communities, thus having great impacts on decomposition activity, nutrient mineralization and primary production (Coleman and Ingham, 1988). These make them one of the most suitable bioindicator organisms for risk assessment in soil (Goats and Edwards, 1988). Eisenia fetida was chosen for this study because of the standardization of acute and chronic ecotoxicological assays. It was considered a suitable model species (Edwards and Coulson, 1992) and was prescribed as test organism (OECD, 1984).

The use of biomarkers to assess the impacts of contaminants on terrestrial ecosystems has noticeably increased over the past few years. Effects of pesticide on earthworms 
have been evaluated with a variety of parameters from growth, reproduction to different kinds of biomarkers (Maboeta et al., 1999; Kammenga et al., 2000). Biomarkers have been developed to test toxicity of substances to earthworms, including cellular changes and DNA damage caused by pesticide exposure, which could serve as early warning signs of impending ecosystem harm (Weeks and Svendsen, 1996; Rajaguru et al., 2003). Overall, the use of biomarkers is becoming increasingly important in the evaluation of effects of contaminants on organisms. Three biomarkers (sperm count, lysosomal membrane stability and DNA damage) were selected for the present study.

Numerous reproductive parameters have been studied in earthworms exposed to various xenobiotics cocoon production, hatching, viability of the worms produced and sexual maturation (Maboeta et al., 1999; Vermeulen et al., 2001; Xiao et al., 2006). Only little attention had been given specifically to the effect of these substances on spermatozoa of earthworms. Sperm count in earthworms shows potential as a sensitive biomarker for measuring effect of inorganic and organic chemicals on reproduction, and alterations in the reproductive process in individual have potential as measurement endpoints for assessing sublethal toxicity of terrestrial pollutants (Cikutovic et al., 1993; Reinecke and Reinecke, 1997; Bustos-Obregon and Goicochea, 2002).

Lysosomal membrane stability is used as an integrative biomarker of multiple stressors. It has great potential as it is nonspecific and could be affected by all the pollutants present (Huggett et al., 1992). One method of determining lysosomal membrane stability is by using a neutral red retention assay. This technique has already proved to be reliable, dose-related and practical to be used in marine (Lowe et al., 1992) and terrestrial systems (Weeks and Svendsen, 1996). The assay has shown to be sensitive to various heavy metals and pesticide pollution (Lowe et al., 1992; Eason et al., 1999; Robidoux et al., 2002).

Comet assay was proved to be a sensitive and useful tool for measuring DNA damage and repair of different chemical pollutants in a variety of organisms, from plants to mammals (Singh et al., 1988; Cotelle and Ferard, 1999; Reinecke and Reinecke, 2004). Its application to earthworm is very valuable for monitoring and detection of genotoxicity of different chemical pollutants in terrestrial ecosystem (Verschaeve and Gilles, 1995; Salagovic et al., 1996; Cotelle and Ferard, 1999). This technique has shown clear dose responses even at relatively low levels of naturally occurring genotoxicants (Fairbairn et al., 1995; Zang et al., 2000). The processing time is relatively short and the assay is less expensive than many other monitoring systems.

Biomarker responses of the earthworm E. fetida to acetochlor exposure were measured (1) to assess the sublethal toxicity of the herbicide acetochlor to earthworms; (2) to determine the potential of these biomarkers for monitoring acetochlor pollution.

\section{Materials and methods}

\subsection{Earthworms and chemicals}

Adult earthworms E. fetida with well developed clitella were used for this test, which were selected from a synchronised culture with the same age for every exposure as well as the control. The selected worms were acclimated for $7 \mathrm{~d}$ to the artificial soil substrate prior to test.

The used acetochlor [2'-ethyl-6-methyl- $N$-(ethoxymethyl)-2-chloroacetanilide] was $90 \%$ miscible oil reagent and was obtained from WU county chemistry factory, Zhejiang Province, China.

\subsection{Soil preparation}

The artificial soil was prepared according to OECD guideline 207 (1984), which was comprised (by dry weight) of $10 \%$ finely ground sphagnum peat, $20 \%$ kaolin clay, $70 \%$ industrial fine sand, with $\mathrm{pH}$ adjusted to 6.5 by addition of calcium carbonate.

\subsection{Treatments}

Earthworms were exposed to an increasing range of concentrations of acetochlor $\left(5,10,20,40\right.$ and $80 \mathrm{mg} \mathrm{kg}^{-1}$ dry soil). Five hundred grams of substrate was placed in each polyethylene plastic containers $(16 \times 10.5 \times 5 \mathrm{~cm})$. The low volume concentration recommended for the agricultural application $\left(1500-3000 \mathrm{ml} \mathrm{ha}^{-1}\right)$ was converted for the surface area of the test containers (Ma et al., 2004). This is equivalent to $5-10 \mathrm{mg} \mathrm{kg}^{-1}$ dry soil. Acetochlor was dissolved in $5 \mathrm{ml}$ acetone and then mixed into a small quantity of fine quartz sand. After the solvent was removed by evaporation for at least $1 \mathrm{~h}$, the sand then mixed thoroughly with the premoistened artificial soil. The final water content was adjusted to $50 \%$ of the maximum water holding capacity. Controls were prepared in a similar way except $5 \mathrm{ml}$ acetone added only. Ten mature earthworms with nearly equivalent masses were added into each container. The container lids were perforated to allow aeration. Earthworms were raised $5 \mathrm{~g}$ fine, urine-free cow dung added per week on the soil surface of each container and were placed in a climate chamber with $20 \pm 1{ }^{\circ} \mathrm{C}$ and $12 \mathrm{D} / 12 \mathrm{~L}$ photoperiod.

\subsection{Sperm count}

Sperm count was determined according to the method of Cikutovic et al. (1993). Sperm count and body mass were determined for earthworms after 5 and 15 days of acetochlor exposure. Five earthworms were removed from each concentration and control. Two counts per earthworm were made. After being weighted, earthworms were transferred into dissecting dishes. Seminal vesicles and testes were dissected out, macerated in $1 \mathrm{ml}$ of PBS (pH 7.4). By teasing apart these organs, sperm released into the fluid 
was counted. The sperm number corrected by the worm weight (in $\mathrm{mg}$ ) was taken to represent the sperm production of each earthworm. Results were expressed as total sperm counts per mg for each worm.

\subsection{Neutral-red retention time (NRRT)}

The neutral-red retention time was measured using the method described by Weeks and Svendsen (1996). Samples of coelomic fluid were collected by inserting a hypodermic needle directly into the coelomic cavity posterior to the clitellum of the worm. Coelomic fluid $(20-50 \mu \mathrm{l})$ equal volume $(50 \mu \mathrm{l})$ of physiological earthworm Ringer was drawn into a hypodermic syringe. The working neutral red concentration was $80 \mu \mathrm{g} \mathrm{ml}^{-1}$, and it was renewed every hour during the measuring process. The coleomic fluid was placed onto a clean slide and stained with an equal volume of neutral red working solution. Each slide was scanned for $2 \mathrm{~min}$ at $5 \mathrm{~min}$ intervals and the number of stained and unstained cell counted until $50 \%$ of cells were red. This time was recorded as the neutral-red retention time.

\subsection{Comet assay}

The coelomocytes of E. fetida after 15 and 30 days of exposure were obtained as described by Eyambe et al. (1991). The worms were rinsed in saline solution $\left(4^{\circ} \mathrm{C}\right)$ and gut contents were expelled by softly pressing the posterior part. Individual worm was placed in an eppendorf tube containing $3 \mathrm{ml}$ extrusion medium and the coelomocytes secreted were collected.

The comet assay (alkali method) was measured according to the method described by Singh et al. (1988). Cell suspensions $(25 \mu \mathrm{l})$ (about $10^{5}$ cells) were mixed with $75 \mu \mathrm{l}$ of $0.5 \%$ low-melting $\left(37^{\circ} \mathrm{C}\right)$ agarose and spreaded on a normal melting agarose-precoated slide. After the agarose solidified, the slides were immersed in freshly prepared cold $\left(4{ }^{\circ} \mathrm{C}\right)$ lysing solution for $2 \mathrm{~h}$ to lyse the coelomocytes. Then, the slides were placed in freshly alkaline buffer (300 $\mathrm{m} \mathrm{M} \mathrm{NaOH}$ and $1 \mathrm{~m} \mathrm{M}$ EDTA, $\mathrm{pH}$ 12.6) $30 \mathrm{~min}$ to unwind DNA. Subsequently, the DNA was electrophoresed for $30 \mathrm{~min}$ at $300 \mathrm{~mA}$ and $25 \mathrm{~V}$. After electrophoresis, the slides were washed with Tris buffer, and $50 \mu 1$ of ethidium bromide $\left(20 \mu \mathrm{g} \mathrm{ml}^{-1}\right)$ was added to each slide. The comet tail lengths (nuclear region + tail) and the width of the comet "head" were measured under a fluorescence microscope (Rajaguru et al., 2003), equipped with an excitation filter of 515-650 nm and a barrier filter of 580-nm. Two slides per treatment were prepared and 25 cells were analyzed from each slide.

\subsection{Statistical analysis}

The data in this study were analyzed by the use of the SPSS program (Standard Version 10.0, SPSS Inc.). LSD test was used to determine the differences between treatments and control. A two-way ANOVA was employed to determine the differences between duration and concentration. The probability level used for the statistical significance was $P<0.05$. All the values were presented as mean $\pm \mathrm{SD}$.

\section{Results}

\subsection{Effect of acetochlor on sperm count}

Sperm count of earthworm depended on the duration and concentration of acetochlor exposure. After 5 days of exposure, number of sperm per mg of body did not changed significantly when earthworms were treated with different concentrations of acetochlor (Table 1). Low and middle concentrations showed higher sperm count. After 15 days of exposure, Sperm count decreased when earthworms were treated with increasing concentration of acetochlor (Table 1). The control earthworms had the highest sperm count, and sperm count decreased to $68.44 \%$ of the control at $5 \mathrm{mg} \mathrm{kg}^{-1}$, but no significant differences were found between them $(P>0.05)$. At the concentration of 40 and $80 \mathrm{mg} \mathrm{kg}^{-1}$, the sperm count decreased significantly to $32.53 \%$ and $32.97 \%$ of the control $(P<0.05)$, respectively. This showed that when the concentrations were more than $40 \mathrm{mg} \mathrm{kg}^{-1}$ acetochlor depressed sperm count significantly after 15 days of exposure.

\subsection{Neutral-red retention time (NRRT)}

After 30 days of exposure, the neutral red retention time for earthworms exposed to increasing concentrations of acetochlor is shown in Fig. 1a. The neutral red retention time for earthworms of control was in excess of $60 \mathrm{~min}$, which decreased steadily to $40.19 \mathrm{~min}$ at the highest concentration of acetochlor $\left(80 \mathrm{mg} \mathrm{kg}^{-1}\right)$. It was shown that retention time decreased significantly $(P<0.01)$ with increasing concentrations of acetochlor exposure. However, the NRRT for earthworms exposed to $5 \mathrm{mg} \mathrm{kg}^{-1}$ of acetochlor was not significantly different $(P>0.05)$ compared to control.

The residue of acetochlor in soil for 30 days is shown in Fig. $1 b$ (Xiao et al., 2006). There was significant correlation

Table 1

Total number of E. fetida spermatozoa per $\mathrm{mg}$ of body weight exposed to different of acetochlor after 5 and 15 days of exposure

\begin{tabular}{lll}
\hline $\begin{array}{l}\text { Acetochlor concentrations } \\
\left(\mathrm{mg} \mathrm{kg}^{-1} \text { soil }\right)\end{array}$ & \multicolumn{2}{l}{ Number of sperm per mg of body $\left(10^{4}\right)$} \\
\cline { 2 - 3 } & 5 days & 15 days \\
\hline 0 & $22.14 \pm 5.67$ & $18.35 \pm 7.03$ \\
5 & $15.03 \pm 3.16$ & $12.56 \pm 4.42$ \\
10 & $16.15 \pm 3.46$ & $12.28 \pm 4.48$ \\
20 & $25.85 \pm 8.27$ & $12.28 \pm 5.65$ \\
40 & $23.57 \pm 8.70$ & $5.97 \pm 4.28^{\mathrm{a}}$ \\
80 & $14.45 \pm 7.74$ & $6.05 \pm 1.53^{\mathrm{a}}$ \\
\hline
\end{tabular}

Sperm per mg of body $\left(10^{4}\right)$.

${ }^{a}$ Significant difference compared to control $(P<0.05), n=5$. 

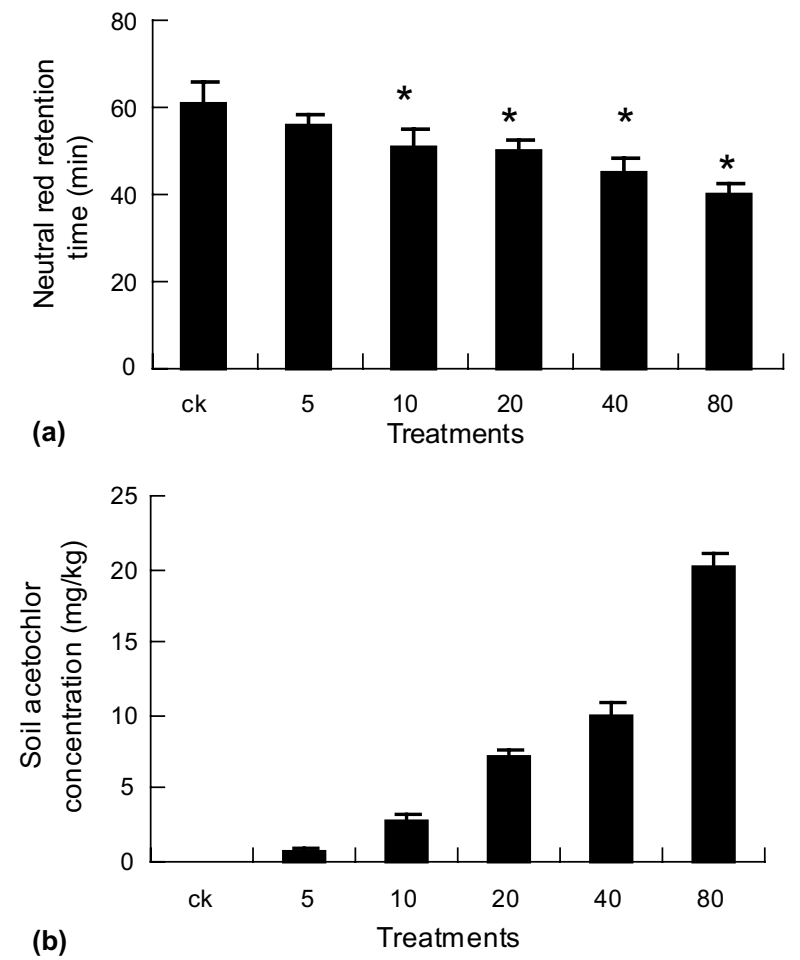

Fig. 1. Neutral red retention times (min) (a) measured for earthworm (E. fetida) exposed to an increasing range of acetochlor concentrations (b) And corresponding the residue of acetochlor in soil $\left(\mathrm{mg} \mathrm{kg}^{-1}\right)$ for $30 \mathrm{~d}$ under laboratory conditions. ${ }^{*}$ Significant difference compared to control $(P<0.05), n=6$.
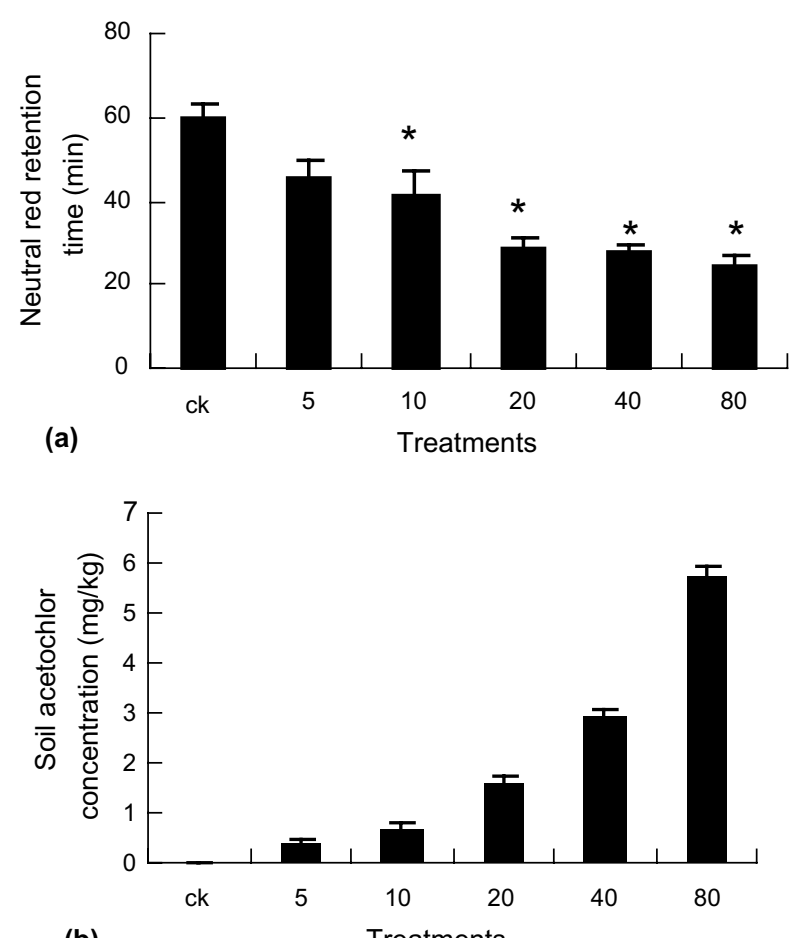

(b)

Fig. 2. Neutral red retention times (min) (a) measured for earthworm (E. fetida) exposed to an increasing range of acetochlor concentrations (b) and corresponding the residue of acetochlor in soil for $60 \mathrm{~d}$ under laboratory conditions. * Significant difference compared to control $(P<0.05), n=6$.
Table 2

DNA damage (length:width ratios) of coelomocytes in E. fetida after exposure to different concentrations of acetochlor

\begin{tabular}{lll}
\hline $\begin{array}{l}\text { Acetochlor concentrations } \\
\left(\mathrm{mg} \mathrm{kg}^{-1} \text { soil }\right)\end{array}$ & \multicolumn{2}{l}{ DNA damage (length:width ratios) } \\
\cline { 2 - 3 } & 15 days & 30 days \\
\hline 0 & $1.08 \pm 0.08$ & $1.11 \pm 0.06$ \\
5 & $1.13 \pm 0.12$ & $1.17 \pm 0.13$ \\
10 & $1.18 \pm 0.19$ & $1.14 \pm 0.10$ \\
20 & $1.20 \pm 0.15$ & $1.22 \pm 0.16$ \\
40 & $1.23 \pm 0.27$ & $1.76 \pm 0.91$ \\
80 & $1.28 \pm 0.34$ & $2.39 \pm 1.19^{\mathrm{a}}$ \\
\hline${ }^{a}$ Significant difference compared to control $(P<0.05)$.
\end{tabular}

between the NRRT and the residual of acetochlor in soil. This fitted the logarithmic model of NRRT $=55.39-$ $4.41 \ln x\left(\mathrm{df}=4, r^{2}=0.902, F=27.73, P=0.013\right)$, where $x$ was the concentration of acetochlor in soil after 30 days of exposure.

A similar observation was made for $E$. fetida exposed to an increasing range of concentrations of acetochlor after 60 days of exposure (Fig. 2a). A significant decrease in NRRT was observed at all exposure concentrations compared to control except the $5 \mathrm{mg} \mathrm{kg}^{-1}$ treatment. The correlation between the NRRT and the residue of acetochlor in soil (Fig. 2b) (Xiao et al., 2006) fitted the logarithmic model of NRRT $=36.77-80.28 \ln x \quad\left(\mathrm{df}=4, \quad r^{2}=0.937, \quad F=\right.$ $44.62, P=0.007)$, where $x$ was the concentration of acetochlor in soil after 60 days of exposure.

\subsection{Comet assay}

The comet assay showed that increasing concentrations of acetochlor resulted in a gradual increase in the mean length:width ratios of DNA. After 15 days of exposure, the length:width ratios of DNA of coelomocytes exposed to different concentrations of acetochlor did not increase significantly (Table 2). However, after 30 days of exposure, the length:width ratios of DNA of coelomocytes at $80 \mathrm{mg} \mathrm{kg}^{-1}$ soil were $2.39 \pm 1.19$. It reached to 2.15 folds of the control and significant differences were found between them $(P<0.001)$. Acetochlor had genotoxicity to E. fetida at $80 \mathrm{mg} \mathrm{kg}^{-1}$ soil after 30 days of exposure.

\section{Discussion}

A main objective in ecotoxicological work is to provide information to estimate ecological risk (Wilson and Crouch, 1987). Biomarkers as tools for risk assessment purposes depend largely on the choice of biomarkers assay, which should both be sensitive and reflect the relevant ecological effect of toxicity. Biomarkers measured in this study showed clear responses to acetochlor exposure in the earthworm E. fetida. The sperm count decreased significantly when the concentration of acetochlor $>40 \mathrm{mg} \mathrm{kg}^{-1}$. Cikutovic et al. (1993) studied the effect of a pesticide on the sperm count of earthworms, the results showed that sperm count was not dependent on the concentration of 
pesticide and showed a threshold effect once the initial depression had occurred. We had the similar conclusion that sperm count of E. fetida decreased sharply when concentration of acetochlor was more than $40 \mathrm{mg} \mathrm{kg}^{-1}$ soil.

The $14 \mathrm{~d}-\mathrm{LC}_{50}$ (half lethal concentration) of acetochlor in artificial soil was $145.3 \mathrm{mg} \mathrm{kg}^{-1}$ and acetochlor decreased significantly the number of juvenile per cocoon when the concentration was $>20 \mathrm{mg} \mathrm{kg}^{-1}$ (Xiao et al., 2006). Our tests showed that sperm count reduced significantly at 40 and $80 \mathrm{mg} \mathrm{kg}^{-1}$ of acetochlor, which was equivalent to the concentration of $1 / 4 \mathrm{LC}_{50}$ to $1 / 2 \mathrm{LC}_{50}$, and the sperm count was affected more sensitive than the decrease of the number of juvenile per cocoon. This is maybe the fact that nucleic acids and other structures in cells are at their most vulnerable during cell division (Reinecke and Reinecke, 1997).

The NRRT is a general stress biomarker and reduced NRRT indicates that exposure has induced a physiological response (Weeks and Svendsen, 1996). The results of the neutral-red retention assay clearly indicated that severe damage to the integrity of the lysosomal membrane had occurred in earthworms treated with increasing concentrations of acetochlor. When the concentrations of acetochlor were more than $10 \mathrm{mg} \mathrm{kg}^{-1}$, the NRRT of earthworms coelomocytes was significantly shorter indicating less intact lysosomal membranes than that was measured at the control. It was shown that earthworms were under physiological stress at field dose $\left(10 \mathrm{mg} \mathrm{kg}^{-1}\right)$ and NRRT can provide a sensitive early warning signal that earthworms were under stress related to acetochlor exposure. The reduced neutral red retention time was correlation with the soil acetochlor residues, and dose-response relationship was found between them. This was in agreement with Maboeta et al. (2002), which was concluded that there was a positive correlation between the increase in copper concentrations in the soil and the decrease in NRRTs.

The comet assay is a simple and sensitive approach for detecting DNA single-strand breakage as well as the assessment of DNA repair in individual cells (Singh et al., 1988). The DNA damage of earthworm coelomocytes was conventionally determined by comet tail lengths and damage classes (Zang et al., 2000; Reinecke and Reinecke, 2004), however it also determined by length:width ratios (Rajaguru et al., 2003). The means DNA length:width ratio showed a high level of DNA damage in earthworms exposed to sediment samples of polluted river (Rajaguru et al., 2003). In this study, when the concentration was less than $40 \mathrm{mg} \mathrm{kg}^{-1}$ soil, length:width ratios of earthworm coelomocytes did not increase significantly, and acetochlor did not show any genotoxicity effects to $E$. fetida even after 30 days of exposure. Acetochlor had not genotoxicity to E. fetida at field dose level. However, after 30 days of exposure at the highest concentration $\left(80 \mathrm{mg} \mathrm{kg}^{-1}\right)$, acetochlor showed a high level of DNA damage to earthworm coelomocytes. Acetochlor caused no genotoxicity to the nasal cells of rats maintained on a diet containing the MTD (supra-maximum tolerated dose) for either one or 18 weeks
(Ashby et al., 1997). Our experiment showed acetochlor has genetoxic effect on E. fetida after 30 days of exposure at $80 \mathrm{mg} \mathrm{kg}^{-1}$ soil. This result suggested that acetochlor was more subchronic toxic to earthworms than to vertebrates. However, comet assay was not a very sensitive parameter to indicate acetochlor contaminated.

\section{Conclusion}

These methods applied in this study to measure biomarkers appeared to form a suitable tool to study the sublethal responses of earthworms to acetochlor exposure. The neutral red retention assay was sensitive for monitoring soil acetochlor pollution even the concentration was low as $10 \mathrm{mg} \mathrm{kg}^{-1}$. NRRT is a reliable biomarker for quick assessment of the impact of acetochlor pollution on E. fetida. Sperm count decreased significantly when the concentration was more than $40 \mathrm{mg} \mathrm{kg}^{-1}$. The DNA damage increased at the highest concentration of $80 \mathrm{mg} \mathrm{kg}^{-1}$, but it was less sensitive to acetochlor pollutant than sperm count and NRRT. This suggests that biomarker measurements of these types (NRRT, sperm count and DNA damage) could be a useful augmentation for use in risk assessments of acetochlor pollution.

\section{Acknowledgement}

This project was supported by Chinese Academy of Sciences Innovation Program (KSCX3-IOZ-04).

\section{References}

Ashby, J., Tinwell, H., Lefevre, P.A., Williams, J., Kier, L., Adler, I.D., Clapp, M.J.L., 1997. Evaluation of the mutagenicity of acetochlor to male rat germ cells. Mutat. Res.-Genet. Tox. En. 393, 263-281.

Bustos-Obregon, E., Goicochea, R.I., 2002. Pesticide soil contamination mainly affects earthworm male reproductive parameters. Asian J. Androl. 4, 195-199.

Cikutovic, M.A., Fitzpatrick, L.C., Venables, B.J., Goven, A.J., 1993. Sperm count in earthworms (Lumbricus terrestris) as a biomarker for environmental toxicology: effects of cadmium and chlordane. Environ. Pollut. 81, 123-125.

Coleman, D.C., Ingham, E.R., 1988. Carbon, nitrogen, phosphorus and sulfur cycling in terrestrial ecosystems. Biogeochemistry 5, 3-6.

Cotelle, S., Ferard, J., 1999. Comet assay in ecotoxicology: a review. Environ. Mol. Mutagen. 34, 246-255.

Eason, C.T., Svendsen, C.O., Halloran, K., Weeks, J.M., 1999. An assessment of the lysosomal neutral red retention test and immune function assay in earthworms (Eisenia andrei) following exposure to chlorpyrifos, benzo- $a$-pyrene ( $\mathrm{B} a \mathrm{P})$, and contaminated soil. Pedobiologia 43, 641-645.

Edwards, P.J., Coulson, J.M., 1992. Choice of earthworms species for laboratory tests. In: Greig-Smith, P.W., Becker, H., Edwards, P.J., Heimbach, F. (Eds.), Ecotoxicology of Earthworms. Intercept, London, pp. 36-43.

Eyambe, G.S., Goven, A.J., Fitzpatrick, L.C., Venables, B.J., Cooper, A.L., 1991. A non-invasive technique for sequential collection of earthworm (Lumbricus terrestris) leucocytes during subchronic immunotoxicity studies. Lab. Anim. 25, 61-67.

Fairbairn, D.W., Olive, P.L., O’Neill, K.L., 1995. The comet assay: a comprehensive review. Mutat. Res. 339, 37-59. 
Goats, G.C., Edwards, C.A., 1988. Prediction of field toxicity of chemicals to earthworms by laboratory methods. In: Edwards, C.A., Neuhauser, E.F. (Eds.), Earthworms in Waste and Environmental Assessment. Academic Publishing, The Hague, pp. 283-294.

Green, T., Lee, R., Moore, R.B., Ashby, J., Willis, G.A., Lund, V.J., Clapp, M.J.L., 2000. Acetochlor-induced rat nasal tumors: further studies on the mode of action and relevance to humans. Regul. Toxicol. Pharm. 32 (7), 127-133.

Hill, A.B., Jefferies, P.R., Quistad, G.B., Casida, J.E., 1997. Dialkylquinoneimine metabolites of chloroacetanilide herbicides induce sister chromatid exchanges in cultured human lymphocytes. Mutat. Res. Genet. Tox. En. 12, 159-171.

Huggett, R.J., Kimerle, R.A., Mehrle Jr., P.M., Bergman, H.L., 1992. BiomarkersBiochemical, Physiological, and Histological Markers of Anthropogenic Stress. Lewis, Boca Raton, FL.

Kammenga, J.E., Dallinger, R., Donker, M.H., Kohler, H.R., Simonsen, V., Triebskorn, R., Weeks, J.M., 2000. Biomarkers in terrestrial invertebrates for ecotoxicological soil risk assessment. Rev. Environ. Contam. Toxicol. 164, 93-147.

Lowe, D.M., Moore, M.N., Evans, B.M., 1992. Contaminant impact on interactions of molecular probes with lysosomes in living hepatocytes from dab Limanda limanda. Mar. Ecol. Prog. Ser. 91, 135-140.

Luo, H.F., Qi, H.Y., Zhang, H.X., 2004. The impact of acetochlor the bacterial diversity in soil. Acta Microbiol. Sin. 44, 519-522.

Ma, Q., Rahman, A., Holland, P.T., James, T.K., McNaughton, D.E., 2004. Field dissipation of acetochlor in two New Zealand soils at two application rates. J. Environ. Qual. 33, 930-938.

Maboeta, M.S., Reinecke, A.J., Reinecke, S.A., 1999. Effects of low levels of lead on growth and reproduction of the Asian earthworm Perionyx excavatus (Oligochaeta). Ecotoxicol. Environ. Saf. 44, 236-240.

Maboeta, M.S., Reinecke, S.A., Reinecke, A.J., 2002. The relation between lysosomal biomarker and population responses in a field population of Microchaetus sp. (Oligochaeta) exposed to the fungicide copper oxychloride. Ecotoxicol. Environ. Saf. 52, 280-287.

OECD, (1984). Organization for Economic Co-operation and Development. Test 207: earthworm, acute toxicity tests. In: Organization for Economic Co-operation and Development (ed.), OECD Guidelines for Testing of Chemicals.

Rajaguru, P., Suba, S., Palanivel, M., Kalaiselvi, K., 2003. Genotoxicity of a polluted river system measured using the alkaline comet assay on fish and earthworm tissues. Environ. Mol. Mutagen. 41, 85-91.
Reinecke, S.A., Reinecke, A.J., 1997. The influence of lead and manganese on spermatozoa of Eisenia fetida (Oligocheata). Soil. Biol. Biochem. 29, 737-742.

Reinecke, S.A., Reinecke, A.J., 2004. The comet assay as biomarker of heavy metal genotoxicity in earthworms. Rev. Environ. Contam. Toxicol. 46, 208-215.

Robidoux, P.Y., Svendsen, C., Sarrazin, M., Hawari, J., Thiboutot, S., Ampleman, G., Weeks, J.M., Sunahara, G.I., 2002. Evaluation of tissue and cellular biomarkers to assess 2,4,6-trinitrotoluene (TNT) exposure in earthworms: effects-based assessment in laboratory studies using Eisenia andrei. Biomarkers 7, 306-321.

Salagovic, J., Gilles, J., Verschaeve, L., Kalina, I., 1996. The comet assay for the detection of genotoxic damage in the earthworms: a promising tool for assessing the biological hazards of polluted sites. Folia. Biol. (Praha). 42, 17-21.

Singh, N.P., McCoy, M.T., Tice, R.R., Schneider, E.L., 1988. A simple technique for quantitation of low levels of DNA damage in individual cells. Exp. Cell. Res. 175, 184-191.

USEPA, 1994. Prevention, pesticide and toxic substances, questions and answers, conditional registration of acetochlor, USEPA, Washington, DC, March 11, 18pp.

Vermeulen, L.A., Reinecke, A.J., Reinecke, S.A., 2001. Evaluation of the fungicide manganese-zinc ethylene bis (dithiocarbamate) (mancozeb) for sublethal and acute toxicity to Eisenia fetida (Oligochaeta). Ecotoxicol. Environ. Saf. 48, 183-189.

Verschaeve, L., Gilles, J., 1995. Single cell gel electrophoresis assay in the earthworm for the detection of genotoxic compounds in soils. Bull. Environ. Contam. Toxicol. 54, 112-119.

Weeks, J.M., Svendsen, C., 1996. Neutral red retention by lysosomes from earthworm (Lumbricus rubellus) coelomocytes: a simple biomarker of exposure to soil copper. Environ. Toxicol. Chem. 15, 1801-1805.

Wilson, R., Crouch, E.A., 1987. Risk assessment and comparisons: an introduction. Science 236, 267-270.

Xiao, N.W., Jing, B.B., Ge, F., Liu, X.H., 2006. The fate of herbicide acetochlor and its toxicity to Eisenia fetida under laboratory conditions. Chemosphere 62, 1366-1373.

Ye, C., 2003. Environmental behavior of the herbicide acetochlor in soil. Bull Environ. Contam. Toxicol. 71, 919-923.

Zang, Y., Zhong, Y., Luo, Y., Kong, Z.M., 2000. Genotoxicity of two novel pesticides for the earthworm, Eisenia fetida. Environ. Pollut. 108, 271-278. 